\title{
Management innovation, pro-innovation organisational culture and enterprise performance: testing the mediation effect
}

\author{
Teresa Kraśnicka ${ }^{1}$ - Wojciech Głód ${ }^{1}$ • \\ Martyna Wronka-Pośpiech ${ }^{1}$
}

Received: 12 February 2016/ Accepted: 30 January 2017/Published online: 24 February 2017

(C) The Author(s) 2017. This article is published with open access at Springerlink.com

\begin{abstract}
The interest in management innovation (MI) is growing and the conviction about its significant role in boosting an enterprise's competitive advantage and performance has recently gained ground. The studies on MI and its relationships with enterprise performance, which are relatively scarce in literature, indicate the complexity of these relationships. This inspired us to propose the management innovation construct and its operationalisation, which allowed for the empirical verification of the relationships between management innovation and enterprise performance. Simultaneously, we adopted the hypothesis on the mediating role of pro-innovation organisational culture. The aim of this article, therefore, is to study the relationships between MI and enterprise performance as well as to determine what role is played by pro-innovation organisational culture in these relationships. In order to do that, we conducted a survey of 301 companies based in Poland. Our research results confirmed the existence of relationships between management innovation and enterprise performance in the survey sample, although they were not very strong. Additionally, the hypothesis about the mediating role of organisational culture was also partially supported. The results of our study enrich the knowledge about the role of MI in stimulating enterprise performance and the role of proinnovation organisational culture. We also discuss the implications for further research and management practice.
\end{abstract}

\footnotetext{
The paper is a result of research project financed by National Science Centre "The impact of management innovation on technological innovation and business performance" (Wpływ innowacji zarządczych na innowacyjność technologiczną i wyniki przedsiębiorstw), NCN nr 2012/07/B/HS4/ 00314.
}

Martyna Wronka-Pośpiech

martyna.wronka@ue.katowice.pl

1 Department of Entrepreneurship and Management Innovation, University of Economics, ul. 1 Maja 50, 40-287 Katowice, Poland 
Keywords Innovation - Management innovation - Organisational culture ·

Enterprise performance

Mathematics Subject Classification L25 · M10 - O31

\section{Introduction}

Innovation is considered to be an important factor conducive to the development of enterprises and their improved competitive advantage. Moreover, its role in the economic growth of a given country is also acknowledged (Alegre et al. 2006; Damanpour and Aravind 2011; Yeh-Yun and Feng-Chuan 2012). The significance of innovation for economic development was already recognized by Schumpeter (1960). Although his understanding of innovation was comprehensive and not limited to new products only, for many years, as Birkinshaw et al. (2008) or Damanpour and Aravind (2011) argue, other researchers have focused mainly on product or technological innovations.

In their extensive literature review Damanpour and Aravind (2011) point out that innovation is conceptualised in many different ways. Most researchers adopt a broad understanding of innovation-as the implementation of meaningful changes in an organisation, which improve not only products/services and technological or administrative processes, but also business procedures, programmes and models, which create new value for an organisation's stakeholders (Timmerman 2009). Crossan and Apaydin take a similarly comprehensive view of innovation, arguing that "it is not limited to production or adoption, assimilation, and exploitation of a value-added novelty in economic and social spheres; renewal and enlargement of products, services, and markets, but it also embraces the development of new methods of production; and establishment of new management systems" (2010, p. 1155). This concept corresponds with the OECD's take on innovation and its measurement, presented in the Oslo Manual (2005), which distinguishes four types of innovation: product, process, organisational and marketing innovation. At the same time, we can observe a growing recognition of the role of non-technological innovation (Volberda et al. 2013) and management innovation (Birkinshaw et al. 2008). Volberda et al. (2013), outlining the state of research on management innovation, note that "empirical basis for measuring management innovation is still patchy and weak". They also point to the future research agenda and emerging themes that are as yet under-researched, such as consequences of MI, i.e. the implications of MI for enterprise performance (2013). This is in line with Mol and Birkinshaw (2012).

In this context, the article aims to present the MI construct and its operationalisation in order to seek answers to two-in our opinion-important questions: what the relationships between MI and enterprise performance are and what role is played by pro-innovation organisational culture in these relationships. The inclusion of organisational culture in our research, in particular pro-innovation organisational culture, stems from the fact that numerous studies presented in the literature confirm the positive relationship of organisational culture and innovation (Martins and 
Terblanche 2003; Khazanchi et al. 2007). Crossan and Apaydin (2010) describe five managerial levers enabling core innovation processes, one of which is organisational culture. Other studies draw attention to the existing "paradoxical view of innovation-supportive culture" (Khazanchi et al. 2007). Taking on research on management innovation and its relationship to enterprise performance is also justified by a relatively low level of innovativeness of Polish enterprises (Global Innovation Index 2015) as well as the necessity to find the way to increase their innovation orientation and awareness, effectiveness, and competitiveness.

\section{Management innovation}

Management innovation (MI) is commonly perceived as generating and implementing meaningfully new solutions concerning processes, rules, methods and structures in the management of an organisation, which have a significant impact on how an organisation's goals are pursued (Birkinshaw et al. 2008) and, potentially, improve its long-term performance (Mothe 2010). A number of definitions are discussed, among others, by Volberda et al. (2013).

The literature review, however, reveals that some scholars conducting research on innovation in management processes and methods do not use the term management innovation. They refer to, for example, organisational innovation (Rahimi et al. 2011), administrative innovation (Tanninen et al. 2008; Damanpour and Aravind 2011), non-technological innovation (Mothe and Thi 2010), or soft innovation (Den Hertog et al. 2006).

Moreover, some researchers argue that the old paradigm of industrial innovation, with technological innovation at its core, will be replaced by the new paradigm of innovation research, recognizing the importance of non-technological innovation (Volberda et al. 2013). MI as new solutions implemented in the management processes, methods or structures is essentially the manifestation of the innovativeness of top management, i.e. their ability to generate, adapt and implement new solutions in an organisation's management.

Our literature review confirms that:

- MI was studied under different terms (organisational, administrative) in the past (Damanpour and Aravind 2011; Meuer 2013) and continues to be included in other research areas, e.g. as organisational innovation (Crossan and Apaydin 2010);

- MI definitions according to different authors seem to draw on a commonly accepted definition from Birkinshaw et al. (2008); according to these authors, management innovation means the invention and implementation of a novel management practice, process, structure, or technique; such innovations should aim to improve a firm's performance (Vaccaro et al. 2012; Mothe and Thi 2010);

- MIs are meaningfully new solutions, i.e. they have not been implemented in a particular enterprise; they can be adapted (e.g. management methods already in use in other organisations) or developed exclusively to meet the needs of a given organisation; 
- attempts are undertaken to combine the two approaches-one proposed by Birkinshaw et al. (2008) and the other developed by OECD specialists (Oslo Manual 2005), which is represented by Hecker and Ganter (2013), who argue that both these conceptions can be considered mutually consistent.

Although in recent years a number of publications on management innovation have been released, the observation, made in 2006, that "despite its importance, management innovation remains poorly managed and poorly understood" is still relevant (Birkinshaw and Mol 2006). One reason may be scarce scientific research that would not only account for the emergence of management innovations, but above all confirm their significance for and impact on a firm's performance. Therefore, taking into consideration the current state of research on management innovation and specific suggestions that such research should be taken further (Volberda et al. 2013), we decided to carry out a study on how management innovation affects enterprise performance. MI appears to be an important element of an organisation's innovativeness, which may positively influence its performance and build its competitive advantage. It seems to be necessary to focus not only on direct links between MI and enterprise performance, but also the role that innovation culture may play in this relationship.

For the purposes of the study, we adopted the assumption proposed by Birkinshaw et al. (2008) and Volberda et al. (2013) that management innovation involves changing a firm's organizational form, practices and processes in a way that is new to the firm and/or industry and results in leveraging the firm's technological knowledge base and its performance in terms of innovation, productivity and competitiveness. The literature review shows that empirical studies of MI adopt a number of different operationalisations of this multidimensional construct (Table 1).

Based on the proposals of MI dimensions identified in the reference literature, we used the following dimensions of management innovation to develop a research tool. We assumed that management innovation as a multidimensional construct comprised:

- a strategic dimension, which describes new development and competition strategies, including innovation, in particular technological (new products/ services), new business models, new innovation sources;

- a structural dimension, determining a scope for the implementation of new solutions in an organisational structure, providing flexibility and adaptiveness to the conditions in which an organisation operates; new structural forms;

- employee motivation and development - the dimension concerning new methods, practices and programmes aiming to boost employees' motivation and develop their skills and competencies (including their innovative activity);

- interorganisational relationships and partnerships - the dimension describing the development and use of new forms of cooperation with different entities in the environment: suppliers, customers/consumers, competitors, scientific institutions, etc.; the creation of open innovation models;

- an ICT dimension; it defines the scope and depth of changes implemented in the sphere of acquiring, collecting, processing and transferring information and knowledge; a new intra- and interorganisational communication tool (Kraśnicka et al. 2016). 
Table 1 Selected examples of the operationalisation of management innovation-the last 10 years

\begin{tabular}{|c|c|c|}
\hline Authors & Dimensions & $\begin{array}{l}\text { Name of } \\
\text { concept }\end{array}$ \\
\hline $\begin{array}{l}\text { Wang and Ahmed } \\
\text { (2004) }\end{array}$ & $\begin{array}{l}\text { Innovativeness } \\
\text { Strategic } \\
\text { Process } \\
\text { Behavioural } \\
\text { Market } \\
\text { Product }\end{array}$ & OI \\
\hline $\begin{array}{l}\text { Elenkov and Manev } \\
\text { (2005) }\end{array}$ & $\begin{array}{l}\text { New human resources development programmes } \\
\text { New planning systems } \\
\text { New control systems } \\
\text { Created organisational units or positions } \\
\text { New approaches to capital resources allocation } \\
\text { New management information systems }\end{array}$ & OI \\
\hline $\begin{array}{l}\text { Birkinshaw et al. } \\
\text { (2008) }\end{array}$ & $\begin{array}{l}\text { Management practices } \\
\text { Processes } \\
\text { Organisational structures } \\
\text { Management techniques }\end{array}$ & MI \\
\hline Mothe and Thi (2010) & $\begin{array}{l}\text { Management practices } \\
\text { Approaches to production organisation } \\
\text { External relations }\end{array}$ & OI \\
\hline Terziovski (2010) & $\begin{array}{l}\text { Innovation strategy } \\
\text { Formal structure } \\
\text { Customer and supplier relationships } \\
\text { Innovation culture } \\
\text { Technological capabilities }\end{array}$ & OI \\
\hline Walker et al. (2011) & $\begin{array}{l}\text { IT technologies } \\
\text { Administrative dimension, embracing new management systems } \\
\text { and processes }\end{array}$ & MI \\
\hline $\begin{array}{l}\text { Damanpour and } \\
\text { Aravind (2011) }\end{array}$ & $\begin{array}{l}\text { Dimension pairs } \\
\text { Strategy versus structure } \\
\text { Innovations in forms and in procedures } \\
\text { Information technology and administrative dimension } \\
\text { Exploratory versus exploitative innovations }\end{array}$ & MI \\
\hline Vaccaro et al. (2012) & $\begin{array}{l}\text { Management practices (setting new rules and ensuing } \\
\text { procedures) } \\
\text { Management processes (changes in routine) } \\
\text { Structures (communication methods, a scope of autonomy and } \\
\text { decision-making competencies) }\end{array}$ & MI \\
\hline Hollen et al. (2013) & $\begin{array}{l}\text { Setting objectives } \\
\text { Motivating employees } \\
\text { Coordination } \\
\text { Decision making }\end{array}$ & MI \\
\hline
\end{tabular}


Table 1 continued

\begin{tabular}{lll}
\hline Authors & Dimensions & $\begin{array}{c}\text { Name of } \\
\text { concept }\end{array}$ \\
\hline $\begin{array}{l}\text { Hecker and Ganter } \\
(2013)\end{array}$ & $\begin{array}{l}\text { Innovation in the firm's workplace organization } \\
\text { Innovation in the firm's knowledge management } \\
\text { Innovation in the firm's external relations } \\
\text { Oamisón and Villar- } \\
\text { López (2014) }\end{array}$ & MI \\
& $\begin{array}{l}\text { Innovations in workplace organization } \\
\text { New organizational methods in external relations }\end{array}$ & OI \\
\hline
\end{tabular}

Source: own elaboration

Legend: MI, the concept strictly related to management innovations; OI, the concept clearly embracing management innovations, which, however, belong to a wider category of organisational innovations

\section{The role of management innovation and its impact on enterprise performance}

Innovations in the area of management may be one of the key factors affecting the performance and development of modern organisations, operating in the turbulent environment. In the new era of innovation, when, characteristically, firms co-create new solutions with consumers and acquire resources from the outside (Prahalad and Krishnan 2008), innovation management will become one of the necessary conditions for the survival of firms or an improvement in their market position, as it shapes a firm's innovation orientation (Wood 2007; Dobni 2010) and, consequently, allows for its implementation by developing new structural solutions and designing organizational processes and human resource management systems (Ahn-Sook 2004), as well as looking for resources outside an organisation. We are convinced that the role of management innovation will gain in importance in the knowledge-based economy, in the increasingly difficult conditions of globalised economies, which require that firms seek entirely new sources of competitive advantage. This involves an ability to find new business models, develop networks (also with consumers) or use new communication tools, which are perceived as an organisation's new competencies. In a constantly changing environment organisations need to develop new competencies, such as adaptability, a capability to integrate and reconfigure internal and external skills and resources, referred to as dynamic competencies (Eisenhardt and Martin 2000). Many scholars emphasise that under global competition management innovation may contribute to building sustained competitive advantage, since it is more difficult to replicate (Teece 2007; Volberda et al. 2013). In the resource-based view, sustained competitive advantage stems from valuable, rare, inimitable and nonsubstitutable resources. The generation of such resources as unique competencies or knowledge may be facilitated by innovation management (Hecker and Ganter 2013). Management innovation may play a critical role in the process of adapting an organisation to changing external conditions, stimulating its flexibility and creating new competencies. 
A great number of studies were conducted on the relationships between innovation and performance, using an array of measures of both innovation and performance, but research on the role of innovation in a firm's growth and success remains relatively scarce (Coad and Rao 2008; Heimonen 2012). In general, research points to the relationship between innovation and a firm's broadly defined performance. This positive influence of innovation on performance finds confirmation in the studies conducted by Hall and Mairesse (1995) or Adams and Jaffe (1996).

The positive relationship between organisational and management innovation and a firm's performance and success is also demonstrated by Kraus et al. (2012), Gallego et al. (2012), and others (Evangelista and Vezzani 2010). On the other hand, literature studies show that some surveys on the relationship between innovation and performance revealed no such connections (Hilami et al. 2010). Other surveys carried out among Malaysia's SMEs confirm that product and process innovations have a positive and significant impact on a firm's performance (Rosli and Sidek 2013).

Interesting conclusions can also been drawn from Darroch's study (2005), which looked into the impact of effective knowledge management on better performance in the area of innovation and financial results. The study did not support the hypothesis of the positive impact of innovation on a firm's financial performance. Other researchers point to the significant difficulties in building a model representing the relationships between innovation and a firm's financial results (Tidd and Bessant 2009).

Cho and Pucik (2005), in turn, sought to confirm the hypotheses concerning the direct connection between innovation, quality and a firm's performance (increased sales, profitability and market value); these hypotheses were supported. The authors propose that innovation on its own is not sufficient to improve a firm's performance or, similarly, quality on its own will not create higher growth. Their study shows that quality affects growth partly through innovation, just the same as the effect of innovation on profitability occurs through quality.

The studies conducted by numerous research teams, as quoted above, clearly demonstrate the inconclusive nature of the results, which undoubtedly points to the complexity of relationships between innovations implemented by firms and their growth and performance. Additionally, our knowledge about the connections between management innovation and firms' financial performance is relatively modest. Few studies that we found in the area also offer inconclusive findings.

Mol and Birkinshaw (2009) underline that "there are contrasting points of view in the literature about the impact of management innovation on firm performance". The study of Walker et al. (2011) shows that management innovation does not have an immediate effect on organizational performance (in the public sector); the impact of MI on organizational performance is fully mediated by performance management (2011, p. 379).

Heij et al. (2012) present similar results, confirming the existence of the relationships between management innovation and organizational performancethey are mediated by exploratory and exploitative product and service innovations. Kraus et al. (2012), on the other hand, partly support the hypothesis that 
management innovation has a positive impact on corporate success and that the positive relationship between management innovation and corporate success is higher in non-family businesses (compared to family-owned firms).

Yet another study, conducted by Mol and Birkinshaw (2009), indicate the existence of the positive effect that the introduction of new management practices has on a firm's future performance in the sample but may itself also be subject to moderation by other variables.

\section{Organisational culture and innovativeness}

As Büschgens et al. point out (2013), since the release of Deal and Kennedy's and Peters and Waterman's books in 1982, we have observed an increased interest in organisational culture as a factor significantly affecting corporate performance. The considerations presented below perceive culture as a set of basic values, norms and convictions universally accepted in a given organisation (Sułkowski 2008). This understanding of culture is related to such concepts of culture as, for example, the one developed by Schein (1996a, b). Most studies on types of culture, both in Poland and worldwide, use the Competing Values Framework and the four types of culture based on this model: the hierarchy, the market, the clan and the adhocracy (Cameron and Quinn 2003).

The studies on organisational culture often discuss the issues relating to its impact on or relationship with innovation (Cavagnoli 2011), so researchers and practitioners are particularly interested in finding an answer to the question what kind of organisational culture affects innovativeness, especially in enterprises. Organisational culture that is conducive to innovation is often referred to as innovation culture (Sharifirad and Ataei 2012; Dobni 2008a, b), innovationsupportive culture (Khazanchi et al. 2007), innovation-oriented culture (De Tienne and Mallette 2012), or culture for innovation (Frohman 1998a, b). Scholars undertaking research in the field aim to identify the features of such organisational culture as well as its directions and impact on innovation (Wang et al. 2010) —in the broadest possible terms.

Numerous studies show that organisational culture is one of the basic determinants of innovation (Crossan and Apaydin 2010; Martins and Terblanche 2003; Khazanchi et al. 2007), treating its role as critical to innovation management. It is the culture supportive of innovation and understood as the social and cognitive environment of an enterprise, shared views about the reality, shared convictions and systems of values that are reflected in consistent employee behaviour (Jassawalla and Sashittal 2002, p. 43). The studies carried out in Poland assume that it is "the entirety of unique cultural values characteristic of every community and organisation that allow for the conduct in innovation activity specific to a given social formation" (Sitko-Lutek 2014). Pro-innovation cultural values comprise, for example, creativity, courage, flexibility, openness, focus on learning (Sitko-Lutek 2014). Moreover, innovation culture embraces trust and openness, responding to challenges and commitment, support and space for new ideas, a specific approach to 
conflict and conflict resolution, risk taking, and freedom to act (Tidd and Bessant 2009).

Khazanchi et al. (2007) point to three dimensions of culture that determine whether culture supports or discourages innovation. These are: value profiles, value congruence (determines the degree to which participants will share them) and valuepractice interactions. The comprehensive model of organisational culture was developed by Dobni. Based on extensive literature studies, the author defined innovation culture as a multidimensional construct, which includes four dimensions (Dobni 2008a, b). The first dimension called Innovation Influence is composed of two factors. Innovation Propensity is understood as the degree to which the organization has a formally established architecture to develop and sustain innovation, while Organisational Constituency is related to the degree to which employees are engaged in the innovation imperative. The second dimensioninnovation infrastructure - is composed of organisational learning and creativity and empowerment. These factors are related to the degree to which the educational opportunities of employees are aligned with innovation objectives. Furthermore, this dimension addresses issues such as creative capacity and the degree of empowerment held by employees. The third dimension called Innovation Influence is composed of two factors. The first factor, market orientation, represents the extent to which workers acquire and disseminate knowledge about customers, competitors and the industry, and whether they know and understand their place in the organization as a larger whole. Value orientation represents the degree to which employees are focused and involved in creating value for clients. The last dimension, innovation implementation, is composed of one factor, namely the Implementation context, and involves the organisation's ability to implement valuable ideas and the ability to proactively adapt systems and processes to changes in the competitive environment (Dobni 2008a, b).

Culture may influence employees' ability to accept innovation as an organisation's basic value and their increased commitment to an organisation. Innovationsupportive culture stimulates the generation of new solutions or their absorption from the outside and contributes to the more effective implementation of creative ideas. Accordingly, we can say that successful innovation is, to a considerable extent, determined by the right organisational culture.

It is also pointed out that the level of innovativeness in an organisation is connected with such organisational culture that supports learning processes, collective decision-making, and the right to experiment and make mistakes (Danneels 2008). According to Dobni (2008a, b), innovation culture is characterized with solution-seeking orientation, values teamwork, supports fast decision-making, and fosters trust and respect in employees.

The literature presents the results of empirical studies, confirming the relationship between organisational culture and innovation (Lau and Ngo 2004). Researchers are particularly interested in determining which type of culture stimulates or hampers innovation. Even though many types of organizational culture have been established since this concept first appeared in the literature (Frohman 1998a, b; Schein 1996a, b; O'Relly et al. 1991), the most widespread and used in many empirical studies is Cameron and Quinn's model (1999), the competing 
values framework (CVF), from which four cultures-adhocracy, clan, market and hierarchy-emerge. The clan culture is based on flexibility and internal focus. In it, the organization acts like a family, promoting teamwork, commitment and involvement. The adhocratic culture promotes flexibility, but its orientation is external. Its objectives include creativity, risk taking, individuality and initiative. The market culture looks for an external perspective through which to differentiate itself from competitors, intended to produce a market leader, but uses the stability and control to achieve its goals of internal and external competitiveness and productivity. Lastly, the hierarchical culture is based on stability and control along with an internal focus. It is characterized by a large number of standards with the objective of achieving efficiency, process standardization, product standardization, etc. (Cameron and Quinn 1999). The four culture types reflect different values about dominant attributes, leadership, bonding and strategic emphases.

Studies show that the type that is the most conducive to innovation is the adhocracy culture, characteristic of the organisation that is flexible, entrepreneurial and focused on the external environment (Jaskyte 2004; Jaskyte and Kisieliene 2006). Lau and Ngo (2004), who studied the effect of the adhocracy (which they refer to as development culture) on innovation in industrial enterprises, formulated similar conclusions. Even more evidence supporting the existence of the relationship between organisational culture and innovation comes from the studies conducted by Naranjo Valencia et al. (2010) or Malaviya and Wadhwa (2005). We should also mention the results of surveys into the links between organisational culture and innovation carried out in Poland. The surveys where organisational culture was studies as one of many organisational factors affecting innovation confirmed the positive relationship between the two variables: the highest level of innovativeness was reported in the organisations whose culture promoted experimentation, creative problem solving and employee initiative (the adhocracy culture) (Pichlak 2012). Krot and Lewicka (2013) carried out the analysis of proinnovation organisational culture in a selected enterprise, which confirmed its market orientation and customer focus. The theme of organisational culture as a factor shaping innovation and creativity in an organisation also emerged in the research conducted by Zdunczyk and Blenkinsopp (2007) in Polish enterprises.

\section{Organisational culture and enterprise performance}

The relationship between corporate culture and performance (also financial) has attracted interest for many years and raises a question about the type of culture that is conducive to high economic performance of enterprises (Kotter and Heskett 1990). The literature review yielded the studies that analysed those relationships. Marcoulides and Heck (1993) tested their own model of culture (comprising such variables as organisational values, climate, employee attitudes and objectives, and others) against the performance of the enterprises, confirming the existence of the connection. Another study involved the analysis of the impact that strong culture exerted on enterprise performance and led to the conclusion that the influences were complex, depended on the type of an environment and its volatility. Apparently, the 
relationship depends on how strongly culture affects organisational learning-in response to internal and external changes (Sørensen 2002). Between the years 1990 and 2007, more than 60 different studies were conducted on the impact of organisational culture on performance. They comprised the total of 1619 enterprises of varied size in 26 countries. The studies confirmed the strong relationship between the variables. This positive correlation embraced over 35 performance indicators (such as a return on investment, an increase in revenue, market share, increased sales of new products, employee productivity) (Abu-Jarad et al. 2010). On the other hand, we managed to find only a relatively limited number of studies exactly on the relationships between pro-innovation organisational culture and enterprise performance. De Tienne and Mallette (2012), for example, confirm the existence of the links between innovation-oriented culture and corporate performance (measured subjectively: product innovations, growth, and a return on investment). Similarly, the study conducted by Wei et al. (2013), dealing with the relationships between the perception of the dimensions of innovation organisational culture and the perception of corporate performance and other variables (e.g. work satisfaction), revealed the relationships between these variables. Finally, we need to mention the results of the survey carried out by Terziovski (2010) among small and medium-sized enterprises. It involved the analysis of the relationships between such variables as, for example, an innovative strategy, a formal organisational structure, innovation culture, and the financial performance of the respondent firms. The study did not support the adopted assumption about positive dependencies between innovation culture and the applied performance indicators (e.g. a successful product launch, reduced wastage, productenhancing innovations, increased quality) (Terziovski 2010).

\section{Management innovation and enterprise performance in the context of organisational culture}

The research results discussed above, both of the studies on the relationships between innovation-including management innovation-and enterprise performance, and the investigation of the correlations between innovation culture and performance, indicate that these connections are complex and not always straightforward. The nature of organisational culture causes that it can create the context for the relationship between MI and enterprise performance, since its impact does not to be direct. We can quote numerous studies that confirm the role of organisational culture in shaping organisational phenomena. Ogbonna and Harris (2010) established that organisational culture of a particular type plays a mediating role in the relationships between a management style and enterprise performance. Moreno-Luzon et al. (2013) studied the impact of TQM on innovation (incremental and radical), accounting for the role of cultural change in their model. Their results imply that organisational culture positively mediates the effects of the TQM practices on radical and incremental innovation. In their studies on innovationsupportive culture, Khazanchi et al. (2007) confirmed the complex nature of the impact exerted by values, which are the content of organisational culture, on the 
implementation of advanced manufacturing technology. This complexity was also revealed in the research carried out by Hajro (2015).

We should add that not only organisational culture, but also organizational innovation climate is attributed with a mediating or moderating role in shaping such phenomena as innovative behaviour and employee commitment, as confirmed by a number of studies (Chien et al. 2013; Salanova et al. 2005).

Thus, there are grounds to conduct further research into management innovation and its impact on enterprise performance with organisational culture as a factor affecting this relationship. We should also remember that the results presented by researchers that confirm a significant impact of organisational culture on the innovativeness of enterprises mostly concentrate on technological innovations. In our research project we focus on the role of pro-innovation organisational culture in shaping the relationships between MI and enterprise performance in order to test its role of a mediator.

\section{Research methodology}

Based on the literature review presented above, we formulated two research questions:

- what is the relationship between MI and enterprise performance,

- what role in shaping this relationship is played by pro-innovation organisational culture.

\subsection{Measurement of management innovation}

Management innovation was evaluated based on the identification of new solutions implemented in five management areas/dimensions-a strategic dimension, a structural dimension, employee motivation and development methods/practices, interorganisational relations and an ICT dimension. Based on the analysis of the MI operationalisations (or organisational innovation), presented in literature (Wang and Ahmed 2004; Mol and Birkinshaw 2009; Vaccaro et al. 2012; Walker et al. 2011) and the research tools that have been used so far, we developed 15 items broken down into the five dimensions (Kraśnicka et al. 2016). The assessment of these items should reflect a level/scope of management innovations generated and implemented in a particular enterprise. Accordingly, we proposed the following way of measuring management innovations:

1. the strategic dimension and structural dimension-four items each; the dimension of employee motivation and development-three items; the dimension of interorganisational relations (partnership) and the ICT dimension-two items;

2. the items describe the scope of meaningful changes/new solutions implemented in the area of management within the last three years (not used so far); 
3. each item is assessed on a 7-point Likert scale (from 1 - "I strongly disagree"- to 7- "I strongly agree").

4. the items are evaluated by top or middle management.

The measurement instrument we have used is presented in Appendix 1 (Table 7).

\subsection{The measurement of pro-innovation organisational culture}

The measurement of pro-innovation organisational culture was conducted based on the tool developed by Dobni (2008a, b). As we mentioned earlier, Dobni's model of pro-innovation organisational culture comprises four dimensions: innovation implementation, innovation intention, innovation infrastructure, and innovation influence. The statements in the questionnaire, consisting of 70 items, describe particular situations in a company or the behaviours and features of employees/ teams, for example, "In our organisation, employees and management trust and respect each other" or "I see myself as a creative, innovative person." Using a seven point Likert scale, the respondents assessed the degree to which a given behaviour or practice occurred in the company (from 1- "I strongly disagree"- to 7- "I strongly agree."). To the authors' knowledge, in Poland, organisational culture has never been researched with the use of the full version of this tool.

\subsection{The measurement of enterprise performance}

In order to measure enterprise performance, we applied Antoncic and Hisrich's concept (2003), which is based on the subjective assessment of six values: an average annual growth in employment, an average annual growth in total sales, market share dynamics (measured with sales), an average return on sales (ROS), an average return on equity (ROE), profitability compared with competitors-in the last 3 years. To assess the value of these indicators, we used a five point scale. Additionally, we applied an aggregate measure - comprising the total mean value of all the indicators.

The next steps in the study were as follows:

- a random selection of the sample of enterprises (nationwide): the survey was conducted in 301 firms (each firm delegated four employees with a minimum 3 years' service, who assessed the statements in the questionnaire on innovation culture - in total 1204 respondents, and one manager responding to the questions about management innovation and performance-in total 301 respondents. This is consistent with the approach suggested by Selltiz et al. (1976) and Nunnally (1978) that the subjects used should be those for whom the instrument was intended.

- a survey (conducted among the employees) and a direct interview (with the managers) followed by the statistical analysis of the results (including the test of the reliability of the research tools). The reliability of the applied tool was tested with Cronbach's alpha coefficient and factor analysis. Kendall's coefficient and the non-parametric analysis of variance (Kruskal-Wallis test by ranks) were 
used to examine the statistical connections between the adopted variables, while Cohen and Cohen's method tested mediation.

The survey was conducted in enterprises based throughout Poland in 2014. In 8 provinces, a random sample of firms was generated from companies registered in the database maintained by the Central Statistical Office. While the 8 provinces were selected based on the number of registered enterprises as a screening criterion, the choice of enterprises was random, yet proportionate.

A total of 301 questionnaires were returned at an overall response rate of $30 \%$. The breakdown of the respondent enterprises by core activity shows that the largest group is labelled "retail and wholesale" (73 enterprises, which amounts to approx. $25 \%$ of the entire sample). The second largest group comprised "industrial processing" and "other service activities" - each category comprising 55 enterprises. In terms of the ownership structure, most of the respondent enterprises are $100 \%$ owned nationally ( $76 \%$ of the total sample). Analysed by size (measured by a number of employees), the respondent enterprises were mostly small businesses (almost 52\%) and medium-sized firms (34.5\%). The majority of the respondent firms had operated in the market for over 10 years $(63 \%)$, while $23 \%$ had the market presence of 6-10 years and the remaining ones had operated for not longer than 5 years.

The first stage of the statistical analysis involved testing the reliability of the tool applied. For this purpose, we conducted the internal consistency analysis with the use of Cronbach's alpha and exploratory factor analysis. Table 2 presents the values of Cronbach's alpha for the five dimensions of management innovation.

The next step involved conducting exploratory factor analysis, which allows for the reduction of a large number of variables to a few mutually uncorrelated factors or principal components. The reduction of the initial set of variables to a few mutually uncorrelated factors occurs without a significant loss of the information that they include. Factor analysis allows for the reduction of a number of variables, i.e. their replacement with factors-metavariables, which are analysed further. The principal components reflect the structure of correlation links between the analysed features. Prior to factor analysis, the adequacy of the selected variables was tested with the Kaiser-Meyer-Olkin statistic. The K-M-O analysis yielded the value of 0.970. A very high value of the $\mathrm{K}-\mathrm{M}-\mathrm{O}$ statistic allows for the application of exploratory factor analysis. Table 3 presents the values of statistics for the factor analysis.

Table 2 Cronbach's alpha values for particular MI dimensions

\section{MI dimensions}

1. Strategic dimension (DMI_1)

2. Structural dimension (DMI_2)

3. Employee motivation and development dimension (DMI_3)

4. Dimension of interorganisational relations (DMI_4)

5. ICT dimension (DMI_5)
Cronbach's alpha

\subsection{3}

0.87

0.79

0.82

0.77 
Table 3 Values of statistics for the factor analysis

\begin{tabular}{lllll}
\hline $\begin{array}{l}\text { MI } \\
\text { dimensions }\end{array}$ & $\begin{array}{l}\text { Own } \\
\text { value }\end{array}$ & $\begin{array}{l}\text { Variance } \\
\text { explanation }\end{array}$ & $\begin{array}{l}\text { Cumulative own } \\
\text { value }\end{array}$ & $\begin{array}{l}\text { Cumulative \% of } \\
\text { variance explanation }\end{array}$ \\
\hline DMI_1 & 7.225 & 48.168 & 7.225 & 48.168 \\
DMI_2 & 1.343 & 8.952 & 8.568 & 57.120 \\
DMI_3 & 1.206 & 8.043 & 9.774 & 65.163 \\
DMI_4 & 0.874 & 5.827 & 10.648 & 70.990 \\
DMI_5 & 0.703 & 4.687 & 11.352 & 75.677 \\
\hline
\end{tabular}

In order to determine the number of factors, we used Jolliffe's criterion, which allowed us to distinguish five factors. This corresponds with the five dimensions of management innovation assumed in the model. Based on the cumulative percentage of variance explained by the factors, we show that the model consisting of the five dimensions of management innovation accounts for $75.7 \%$ of total variability.

Our measure of organizational culture is based on the innovation culture construct developed by Dobni (2008a, b). This measure has been used in previous research on organizational culture and has been validated (Dobni 2008a, b, 2010). We use four key dimensions of innovation culture proposed by the author: Innovation Implementation, Innovation Intention, Innovation Infrastructure and Innovation Influence. Cronbach's alpha values indicate the consistency of the analysed items in the four dimensions of pro-innovation culture (dimension $1=0.95$, dimension $2=0.97$, dimension $3=0.95$, dimension $4=0.95$ ).

\section{Results}

Aiming to answer the research question concerning the relationships between MI and the performance of the respondent enterprises, we first calculated the mean assessments of the intensity of management innovation (Table 4). The compilation of the measurement results for MI shows that managers allocated the highest scores to the strategic dimension and the dimension of interorganisational relations (4.7), while the lowest scores were given to the employee motivation and development dimension.

Table 4 Dimensions of management innovationresearch results

\begin{tabular}{ll}
\hline Dimensions of management innovation & Mean assessment \\
\hline DMI_1 & 4.70 \\
DMI_2 & 4.61 \\
DMI_3 & 4.26 \\
DMI_4 & 4.70 \\
DMI_5 & 4.43 \\
\hline
\end{tabular}




\subsection{Enterprise performance}

Based on Antoncic and Hisrich's (2003) concept of enterprise performance measurement (Antoncic and Hisrich 2003), we generated the data on enterprise performance according to six indicators (the data are presented in Appendix 2). The figures imply that:

- only in 93 enterprises (31\%) the managers indicated a slight increase in employment (by a maximum of $4 \%$ ) in the last 3 years;

- the highest percentage of enterprises in the sample (more than 32\%) are the enterprises that reported a growth in sales not exceeding $4 \%$; over $22 \%$ of the enterprises did not report increased sales;

- the highest percentage of the respondent firms are the enterprises that reported unchanged market share dynamics (approx. 40\%); the managers of only 19 enterprises indicated significant growth dynamics;

- in the case of a return on sales and a return on equity, the highest proportion of the enterprises reported an increase of $0-4 \%$ (38.9\% for ROS and $45.2 \%$ for ROE, respectively); in the case of $6 \%$ of the respondent enterprises we did not receive this response due to confidentiality issues;

- in the majority of the enterprises, profitability remained unchanged or increased moderately in the recent years (in $85 \%$ of firms); only 18 enterprises (6\% of the sample) reported a fall in profitability.

Appendix 3 contains the compilation of Kendall's correlation coefficients and the results of non-parametric analysis of variance (Kruskal-Wallis test by ranks). Based on the statistical analysis of the relationships, we arrived at the following conclusions:

- relationships exist between all the dimensions of management innovation and an employment growth, a growth in sales and market share dynamics (total sales) in the respondent enterprises,

- relationships exist between the dimensions of management innovation and an average return on sales (they concern the strategic dimension-DMI_1, the dimension of interorganisational relations-DMI_4, and the ICT dimensionDMI_5),

- we observed the relationship only between the strategic dimension of MI (DMI_1) and an average return on equity-ROE,

- relationships exist between all the dimensions of MI and enterprise profitability-as compared with important competitors.

\subsection{Testing the role of pro-innovation organisational culture}

Table 5 presents the results of the assessment of organisational culture in the respondent enterprises, showing the means for the four dimensions of organisational culture. The figures remain within the range of 4.68-4.81, so slightly above the mean value. The implementation dimension, which reflects an 
Table 5 Mean assessment of the dimensions of proinnovation organisational culture

\begin{tabular}{ll}
\hline Dimension of organisational culture & Mean assessment \\
\hline Innovation implementation DOC_1 & 4.68 \\
Innovation intention DOC_2 & 4.81 \\
Innovation infrastructure DOC_3 & 4.79 \\
Innovation influence DOC_4 & 4.78 \\
\hline
\end{tabular}

Table 6 The results of testing mediation with the use of Cohen and Cohen's method

\begin{tabular}{lllll}
\hline & DOC_1 & DOC_2 & DOC_3 & DOC_4 \\
\hline DMI_1 & $\mathbf{X}$ & $\mathbf{X}$ & $\mathbf{x}$ & $\mathbf{x}$ \\
DMI_2 & - & - & - & - \\
DMI_3 & - & $\mathbf{X}$ & $\mathbf{X}$ & $\mathbf{X}$ \\
DMI_4 & $\mathbf{X}$ & $\mathbf{X}$ & $\mathbf{X}$ & $\mathbf{X}$ \\
DMI_5 & - & - & - & - \\
\hline
\end{tabular}

$X$ mediation on the level of significance $(<0.05)$

$x$ mediation on the level of significance $(<0.05 ; 0.1>)$

enterprise's ability to implement new solutions, including the necessary resources, was ranked relatively the lowest. The other three dimensions were ranked similarly to each other.

The analysis of the role of innovation culture as a mediator between management innovation and enterprise performance was conducted based on the approach developed by Cohen and Cohen (2003). In order to examine a mediation effect according to Cohen and Cohen's approach, we used the Sobel and Aroian test. It is a conservative test, suitable for samples larger than 50. Detailed calculations are presented in Appendix 4. The results of the statistical analysis of the role of organisational culture as a mediator between management innovation and enterprise performance are shown in Table 6.

Table 6 shows that the four dimensions of pro-innovation organisational culture mediate the relationship between the strategic dimension (DMI_1) and the dimension of interorganisational relations (DMI_4) with enterprise performance-but on varying levels of significance. In the case of the relationship between the employee motivation and development dimension (DMI_3) and enterprise performance, three dimensions of culture play a mediating role: Innovation Intention, Innovation Infrastructure and Innovation Influence. In Table 6, the "X" symbol is used to denote the mediation effect at the $<0.05$ level of significance, while the " $x$ " symbol represents the same effect at the level of statistical significance within a range of $<0.05 ; 0.1>$. The effect of mediation between the structural dimension and the ICT dimension with enterprise performance was not detected. 


\section{Discussion}

Based on the analyses conducted, we revealed a positive relationship between management innovation and enterprise performance, although the dependencies are not very strong (the highest values of correlation coefficients stood at 0.265 ). The results indicate that not only technological innovations, but also other types of innovations may contribute to improved enterprise performance. This should encourage managers to seek new solutions in the area of management-new operational strategies, new organisational structures, more effective employee motivation techniques etc. Our research results are convergent with the results of other scholars (Kraus et al. 2012), but we should also note that some studies on the links between MI and organisational performance indicate the mediating role that different factors play in these relationships. In their study, Walker et al. (2011) pointed to the variable of performance management, while Heij et al. (2012) identified a mediating variable as exploratory and exploitative product and service innovations.

The second research question concerned the role of pro-innovation organisational culture in shaping the relationship between $\mathrm{MI}$ and enterprise performance. Our study indicates that organisational culture plays a partly mediating role in the relationships between management innovation and enterprise performance. This means that in certain areas organisational culture strengthens the connection between the variables. In accordance with Cohen and Cohen's approach, which we adopted, the relationships involved three MI dimensions (strategic, employee motivation and development, interorganisational relations).

Our research results encourage further attempts to seek the underlying causes of such dependencies. However, this is difficult as there has been little empirical research on management innovation practices reported in the existing literature. Most studies, also those conducted in Poland, confirm the positive impact that product or technological innovations have on performance (Pichlak 2012). Studies also confirm the positive impact of organisational culture on product and process innovations (De Tienne and Mallette), probably stronger than on management innovation. Furthermore, Dobni's (2008a, b) pro-innovation organisational culture model is not in any particular way focused on management innovation, but rather on innovation in general. On the other hand, taking into account relationships between organisational culture and enterprise performance, results of other studies indicate that "organizational culture has a deep impact on the performance of employees that can cause to improve in the productivity and enhance the organizational performance" (Shahzad and Luqman 2012). Shahzad and Luqman (2012) review over 60 research studies conducted between 1990 and 2007 to find out the cultural impact on organisational performance. These studies mostly confirm a positive association between strong culture and performance improvement, but mainly show the positive impact of culture on employee performance (Shahzad and Luqman 2012). 
The complexity of our research subject, including the ambiguous role of proinnovation culture, is also pointed out by Khazanchi et al. (2007), who defined it as "a paradoxical view of innovation-supportive culture". Time-delayed effects of innovation should also be taken into consideration, as management innovations are likely to take longer to exert their influence than it may be in the case of technological innovations. Furthermore, our study adopted the perspective of the last 3 years, as suggested by the Oslo Manual methodology (2005).

Despite some ambiguities regarding relationships in question, we think that managers should be encouraged both to look for new solutions in the field of management and to create pro-innovation culture. They should develop organisational culture conducive to innovation and initiate endeavours to deliberately shape this kind of culture in all its dimensions. It is particularly important that employee commitment is fostered by developing formal solutions to stimulate and implant innovation activity. This activity should become the main theme of employee training and development, focusing on employees' creativity and cooperation as well as strengthening market orientation. Initiatives undertaken in this area should be reflected in an organisation's vision, mission and goals. They should also become a permanent element of its business model and practice.

It is also worthwhile to mention that we successfully verified the usefulness of the tool developed by Dobni (2008a, b) for enterprises operating in Poland and confirmed its high reliability. Yet, we also observed that the survey questionnaire on pro-innovation organisational culture is found time consuming by respondents due to its length (it contains 70 items). This may discourage managers from using the tool for diagnostic purposes.

The research results come with a number of limitations that stem mainly from the known shortcomings of quantitative research conducted with a survey method. The assessments of all the variables examined are based on the respondents' subjective opinions. This might cause a bias due to the respondents' tendency to reply positively to questions related to performance and management innovation. The inclusion of objective measures from other sources, especially measures of performance, could reinforce the conclusions of this study. Although the sample of enterprises investigated in Poland was relatively large, in each respondent enterprise only one manager, who was not always a member of top management, evaluated management innovation and enterprise performance. Moreover, the questionnaire on organisational culture was completed by only four employees selected by a manager in a given enterprise. In further research, it is imperative to increase the number of respondents, especially those who are to evaluate organisational culture. Moreover, we can assume that the use of longitudinal analysis would be required to investigate the entire complexity of the relationships between management innovation and enterprise performance. Since there has been insufficient empirical research on management innovation practices reported in the extant literature, it is difficult to determine how industry classification or industry size might bias the results. 
In order to decrease the risk of bias during the design and administration of our research we assured respondent confidentiality. This is aimed at reducing common method bias by making respondents less likely to modify their answers due to social desirability or how they think others may expect them to answer.

We are also aware of the potential common method bias as reported by Chang et al. (2010) and the need to perform validity checks. However, during the study we were unable to gather additional data to address this issue. Thus, we suggest some further developments in the topic, which in our opinion, should be carried out twofold. We suggest using alternative measure of the dependent variable, which is enterprise performance (Antoncic and Hisrich 2003), for example, the measure of competitiveness. Alternatively, another approach to measuring independent variable, namely management innovation would be welcomed to help reduce the common method variance problem. Additionally, it would be worthwhile to measure independent and depended variables in different points of time. Thus, further studies should focus on asserting the time lag between measuring two main constructs in our model. In this study, however, this approach was not possible. We strongly believe that such research approach would help to address CMV (common method variance) issue and to improve the validity of research results. To address potential common method variance, also two or more sources of information about dependent and independent variables might be used. Because of financial limitations such an approach was not possible in this study.

Future studies should also aim to elaborate on the underlying reasons for the findings presented in the paper. In forthcoming research into relationships between management innovation and enterprise performance, including organisational culture, we should seek an explanation why its mediating role was not revealed in all the MI dimensions and what the reasons for these differences are. Moreover, it could be argued that further research into the relationships between management innovation and enterprise performance taking into account the role of organisational culture should employ both different methods to measure the relevant variables and more advanced statistical methods. In further studies it would be worthwhile to use other mediating variables, such as transformation leadership, or moderating variables, such as environment, as well as to conjoin moderation with mediation. It also seems reasonable to focus on the implications of management innovation in the long run-especially using qualitative research. Future research in other countries should be undertaken in order to evaluate whether our results might be country-specific.

\section{Conclusion}

The research results presented in this article make a valuable contribution to the knowledge about the relationships between a specific type of innovation that management innovation is and enterprise performance. They also enrich the 
knowledge about the strength of management innovation and organisational culture as well as the performance of Polish enterprises. This way, they fill the existing gap in the knowledge about the significance of this rather underestimated type of innovation, in the area where studies are relatively few. At the same time, our research results show the complexity of the relationships under study and encourage further questions about their nature.

The study used the original MI construct and its operationalisation together with our own research tool designed to study and evaluate management innovation. In our research on the relationships between MI and the performance of enterprises in Poland, we took into account the role of pro-innovation organisational culture. We tested a mediation effect with the use of Cohen and Cohen's method. The analysis supported the mediating role of organisational culture in the relationship between management innovation and enterprise performance, although the role does not concern all the MI dimensions. Based on the empirical survey, we confirmed relatively weak, yet statistically significant dependencies between the variables. Despite the limitations of the study, its results allow for the formulation of a number of conclusions addressed to managers. They should not, for example, focus only on technological innovation, but they need to acknowledge the value of innovative solutions in the area of management. The study might encourage managers to build pro-innovation organisational culture as it can contribute to an organisation's increased effectiveness. Managers should become more efficient in inspiring innovation activity among employees by using adequate motivation tools. The organisations that choose to grow through innovative solutions in management should create the environment that promotes transparency and open discussion, trust and mutual respect between management and employees. Summing up, proinnovation culture, to a certain extent, "invigorates" the organisational mechanisms and structures that are responsible for supporting new ideas and ways of thinking and working, which can facilitate the implementation of management innovation and strengthen its impact on enterprise performance. We can assume that innovation culture plays a positive role in the implementation of new solutions in management and their influence on organisational performance, although its mediating role probably does not affect all the MI dimensions.

Given the limitations of our study, further exploration of the management innovation theme seems fully justified, especially that priorities in management innovation research are numerous and challenging (Volberda et al. 2013).

Open Access This article is distributed under the terms of the Creative Commons Attribution 4.0 International License (http://creativecommons.org/licenses/by/4.0/), which permits unrestricted use, distribution, and reproduction in any medium, provided you give appropriate credit to the original author(s) and the source, provide a link to the Creative Commons license, and indicate if changes were made.

\section{Appendix 1}

See Table 7. 
Table 7 Management innovation-measurement instrument and Cronbach's alphas for particular items and management innovation dimension (CFA)

Cronbach's

alpha

Strategic dimension

In the last 3 years in our firm we have implemented significant changes:

1. In the competition strategy, orienting it towards new markets and/or opening new market space

2. In the corporate development strategy so that innovations could be an important/main source of competitive advantage

3. In the ways of monitoring the environment in order to seize opportunities for developing (and/or adapting) innovations (product, technological, marketing)

4. New management methods/systems facilitating the implementation of strategies (e.g. 0.830 Strategic Score Card, TQM)

Structural dimension

In the last 3 years in our firm we have introduced:

5. Meaningful/radical changes in principles and procedures

6. Changes in the scope of tasks and responsibilities of our employees and the ways of coordinating assignments

7. New organisational solutions in the communication systems in divisions (branches, subsidiaries) and between them

8. New forms of organisational structures, new branches/units/positions

0.817

Employee motivation and development dimension

In the last 3 years we have introduced entirely new and considerably modified:

9. Remuneration systems promoting employee innovative behaviour and increased productivity

10. Systems/methods for tasks planning and employee/team performance control

11. PRACTICES/programmes aiming at human resource development (e.g. promotion, 0.677 training, mentoring, coaching systems)

Interorganisational relations (partnership) dimension

In the last 3 years in our firm we have created:

12. Unique relations with customers aiming to identify their needs, respond to these needs more quickly and retain customer loyalty

13. New forms of cooperation with suppliers in order to streamline operational efficiency, develop new technologies, etc.

\section{ICT dimension}

In the last 3 years in our firm we have implemented new or heavily modified:

14. IT systems supporting managerial decision-making processes

15. IT systems and other communication tools or practices in order to acquire and collect information and knowledge and disseminate them among employees (e.g. Intranet, knowledge bases) 


\section{Appendix 2}

\section{Performance indicators in the respondent enterprises}

Below we present the average annual employment growth rates (Table 8), the average returns on sales-ROS—and the average returns on equity-ROE (Table 9), and profitability compared with the competition (Table 10).

Table 8 Employment growth rates in the respondent enterprises

\begin{tabular}{lcc}
\hline Growth in employment & Number of enterprises & Share (\%) \\
\hline It did not grow & 117 & 38.9 \\
It grew slightly (up to 4\%) & 93 & 30.9 \\
It grew from 5 to 9\% & 51 & 16.9 \\
It grew from 10 to 19\% & 25 & 8.3 \\
It grew by 20\% and more & 15 & 5.0 \\
Total & 301 & 100.0 \\
\hline
\end{tabular}

Table 9 ROS and ROE in the respondent enterprises

\begin{tabular}{|c|c|c|c|c|}
\hline & \multicolumn{2}{|l|}{ Return on sales } & \multicolumn{2}{|l|}{ Return on equity } \\
\hline & Number of enterprises & Share $(\%)$ & Number of enterprises & Share $(\%)$ \\
\hline No response & 18 & 6.0 & 19 & 6.3 \\
\hline Below 0\% & 9 & 3.0 & 10 & 3.3 \\
\hline From 0 to $4 \%$ & 117 & 38.9 & 136 & 45.2 \\
\hline From 5 to $9 \%$ & 93 & 30.9 & 100 & 33.2 \\
\hline From 10 to $19 \%$ & 49 & 16.3 & 29 & 9.6 \\
\hline Above $20 \%$ & 15 & 5.0 & 7 & 2.3 \\
\hline Total & 301 & 100.0 & 301 & 100.0 \\
\hline
\end{tabular}

Table 10 Profitability of the respondent enterprises

\begin{tabular}{lcc}
\hline Profitability of sales & Number of enterprises & Share (\%) \\
\hline Lower & 18 & 6.0 \\
The same & 132 & 43.9 \\
Moderately higher & 122 & 40.5 \\
Significantly higher & 25 & 8.3 \\
Substantially higher & 4 & 1.3 \\
Total & 301 & 100.0 \\
\hline
\end{tabular}




\section{Appendix 3}

Relationships between the dimensions of management innovation and enterprise performance (Table 11).

Table 11 Kendall's correlation coefficients in the relationship between the MI dimensions and enterprise performance

Employment Annual Market share ROS ROE Profitability
sales dynamics

\begin{tabular}{|c|c|c|c|c|c|c|}
\hline \multicolumn{7}{|c|}{ Strategic dimension } \\
\hline Tau & 0.187 & 0.245 & 0.265 & 0.227 & 0.108 & 0.206 \\
\hline $\mathrm{N}$ & 301 & 301 & 301 & 283 & 282 & 301 \\
\hline$p$ & 0.000 & 0.000 & 0.000 & 0.000 & 0.007 & 0.000 \\
\hline \multicolumn{7}{|c|}{ Structural dimension } \\
\hline Tau & 0.207 & 0.186 & 0.206 & 0.091 & 0.048 & 0.092 \\
\hline $\mathrm{N}$ & 301 & 301 & 301 & 283 & 282 & 301 \\
\hline$p$ & 0.000 & 0.000 & 0.000 & 0.023 & 0.233 & 0.018 \\
\hline \multicolumn{7}{|c|}{$\begin{array}{l}\text { Employee motivation and } \\
\text { development dimension }\end{array}$} \\
\hline Tau & 0.220 & 0.197 & 0.216 & 0.127 & 0.077 & 0.155 \\
\hline $\mathrm{N}$ & 301 & 301 & 301 & 283 & 282 & 301 \\
\hline$p$ & 0.000 & 0.000 & 0.000 & 0.001 & 0.054 & 0.000 \\
\hline \multicolumn{7}{|c|}{$\begin{array}{l}\text { Interorganisational relations } \\
\text { (partnership) dimension }\end{array}$} \\
\hline Tau & 0.222 & 0.212 & 0.196 & 0.154 & 0.057 & 0.179 \\
\hline $\mathrm{N}$ & 301 & 301 & 301 & 283 & 282 & 301 \\
\hline$p$ & 0.000 & 0.000 & 0.000 & 0.000 & 0.152 & 0.000 \\
\hline \multicolumn{7}{|c|}{ ICT dimension } \\
\hline Tau & 0.146 & 0.194 & 0.259 & 0.210 & 0.113 & 0.166 \\
\hline $\mathrm{N}$ & 301 & 301 & 301 & 283 & 282 & 301 \\
\hline$p$ & 0.000 & 0.000 & 0.000 & 0.000 & 0.005 & 0.000 \\
\hline
\end{tabular}

Significant correlations are shown in bold $p$ value-significant if $p<0.05$ (level of observed likelihood)

The results of non-parametric analysis of variance (Kruskal-Wallis test by ranks) are presented in Tables 12, 13, 14, 15, 16 and 17. 
Table 12 Relationships between dimensions of management innovation and employment

\begin{tabular}{llllll}
\hline & $\begin{array}{l}\text { Strategic } \\
\text { dimension }\end{array}$ & $\begin{array}{l}\text { Structural } \\
\text { dimension }\end{array}$ & $\begin{array}{l}\text { Employee motivation } \\
\text { and development } \\
\text { dimension }\end{array}$ & $\begin{array}{l}\text { Interorganisational } \\
\text { relations (partnership) } \\
\text { dimension }\end{array}$ & $\begin{array}{l}\text { ICT } \\
\text { dimension }\end{array}$ \\
\hline Chi square & 20.528 & 22.538 & 26.431 & 26.809 & 14.690 \\
$d f$ & 4 & 4 & 4 & 4 & 4 \\
$p$ & $\mathbf{0 . 0 0 0}$ & $\mathbf{0 . 0 0 0}$ & $\mathbf{0 . 0 0 0}$ & $\mathbf{0 . 0 0 0}$ & $\mathbf{0 . 0 0 5}$ \\
\hline
\end{tabular}

Significant correlations are shown in bold

Table 13 Relationships between dimensions of management innovation and annual sales

\begin{tabular}{llllll}
\hline & $\begin{array}{l}\text { Strategic } \\
\text { dimension }\end{array}$ & $\begin{array}{l}\text { Structural } \\
\text { dimension }\end{array}$ & $\begin{array}{l}\text { Employee motivation } \\
\text { and development } \\
\text { dimension }\end{array}$ & $\begin{array}{l}\text { Interorganisational } \\
\text { relations (partnership) } \\
\text { dimension }\end{array}$ & $\begin{array}{l}\text { ICT } \\
\text { dimension }\end{array}$ \\
\hline Chi-square & 30.625 & 21.299 & 22.991 & 25.612 & 19.548 \\
$d f$ & 4 & 4 & 4 & 4 & 4 \\
$p$ & $\mathbf{0 . 0 0 0}$ & $\mathbf{0 . 0 0 0}$ & $\mathbf{0 . 0 0 0}$ & $\mathbf{0 . 0 0 0}$ & $\mathbf{0 . 0 0 1}$
\end{tabular}

Significant correlations are shown in bold

Table 14 Relationships between dimensions of management innovation and market share dynamics

\begin{tabular}{llllll}
\hline & $\begin{array}{l}\text { Strategic } \\
\text { dimension }\end{array}$ & $\begin{array}{l}\text { Structural } \\
\text { dimension }\end{array}$ & $\begin{array}{l}\text { Employee motivation } \\
\text { and development } \\
\text { dimension }\end{array}$ & $\begin{array}{l}\text { Interorganisational } \\
\text { relations (partnership) } \\
\text { dimension }\end{array}$ & $\begin{array}{l}\text { ICT } \\
\text { dimension }\end{array}$ \\
\hline Chi-square & 38.954 & 27.687 & 23.102 & 24.697 & 33.400 \\
$d f$ & 4 & 4 & 4 & 4 & 4 \\
$p$ & $\mathbf{0 . 0 0 0}$ & $\mathbf{0 . 0 0 0}$ & $\mathbf{0 . 0 0 0}$ & $\mathbf{0 . 0 0 0}$ & $\mathbf{0 . 0 0 0}$ \\
\hline
\end{tabular}

Significant correlations are shown in bold

Table 15 Relationships between dimensions of management innovation and ROS

\begin{tabular}{llllll}
\hline & $\begin{array}{l}\text { Strategic } \\
\text { dimension }\end{array}$ & $\begin{array}{l}\text { Structural } \\
\text { dimension }\end{array}$ & $\begin{array}{l}\text { Employee motivation } \\
\text { and development } \\
\text { dimension }\end{array}$ & $\begin{array}{l}\text { Interorganisational } \\
\text { relations (partnership) } \\
\text { dimension }\end{array}$ & $\begin{array}{l}\text { ICT } \\
\text { dimension }\end{array}$ \\
\hline Chi square & 30.397 & 5.564 & 8.765 & 11.697 & 20.452 \\
$d f$ & 4 & 4 & 4 & 4 & 4 \\
$p$ & $\mathbf{0 . 0 0 0}$ & 0.234 & $\mathbf{0 . 0 6 7}$ & $\mathbf{0 . 0 2 0}$ & $\mathbf{0 . 0 0 0}$ \\
\hline
\end{tabular}

Significant correlations are shown in bold 
Table 16 Relationships between dimensions of management innovation and ROE

\begin{tabular}{llllll}
\hline & $\begin{array}{l}\text { Strategic } \\
\text { dimension }\end{array}$ & $\begin{array}{l}\text { Structural } \\
\text { dimension }\end{array}$ & $\begin{array}{l}\text { Employee motivation } \\
\text { and development } \\
\text { dimension }\end{array}$ & $\begin{array}{l}\text { Interorganisational } \\
\text { relations (partnership) } \\
\text { dimension }\end{array}$ & $\begin{array}{l}\text { ICT } \\
\text { dimension }\end{array}$ \\
\hline Chi-square & 11.318 & 6.135 & 3.466 & 7.243 & 6.556 \\
$d f$ & 4 & 4 & 4 & 4 & 4 \\
$p$ & $\mathbf{0 . 0 2 3}$ & 0.189 & 0.483 & 0.124 & 0.161 \\
\hline
\end{tabular}

Significant correlations are shown in bold

Table 17 Relationships between dimensions of management innovation and profitability

\begin{tabular}{llllll}
\hline & $\begin{array}{l}\text { Strategic } \\
\text { dimension }\end{array}$ & $\begin{array}{l}\text { Structural } \\
\text { dimension }\end{array}$ & $\begin{array}{l}\text { Employee motivation } \\
\text { and development } \\
\text { dimension }\end{array}$ & $\begin{array}{l}\text { Interorganisational } \\
\text { relations (partnership) } \\
\text { dimension }\end{array}$ & $\begin{array}{l}\text { ICT } \\
\text { dimension }\end{array}$ \\
\hline Chi-square & 22.367 & 13.638 & 19.658 & 18.300 & 24.187 \\
$d f$ & 4 & 4 & 4 & 4 & 4 \\
$p$ & $\mathbf{0 . 0 0 0}$ & $\mathbf{0 . 0 0 9}$ & $\mathbf{0 . 0 0 1}$ & $\mathbf{0 . 0 0 1}$ & $\mathbf{0 . 0 0 0}$
\end{tabular}

Significant correlations are shown in bold

\section{Appendix 4}

See Tables 18 and 19. 


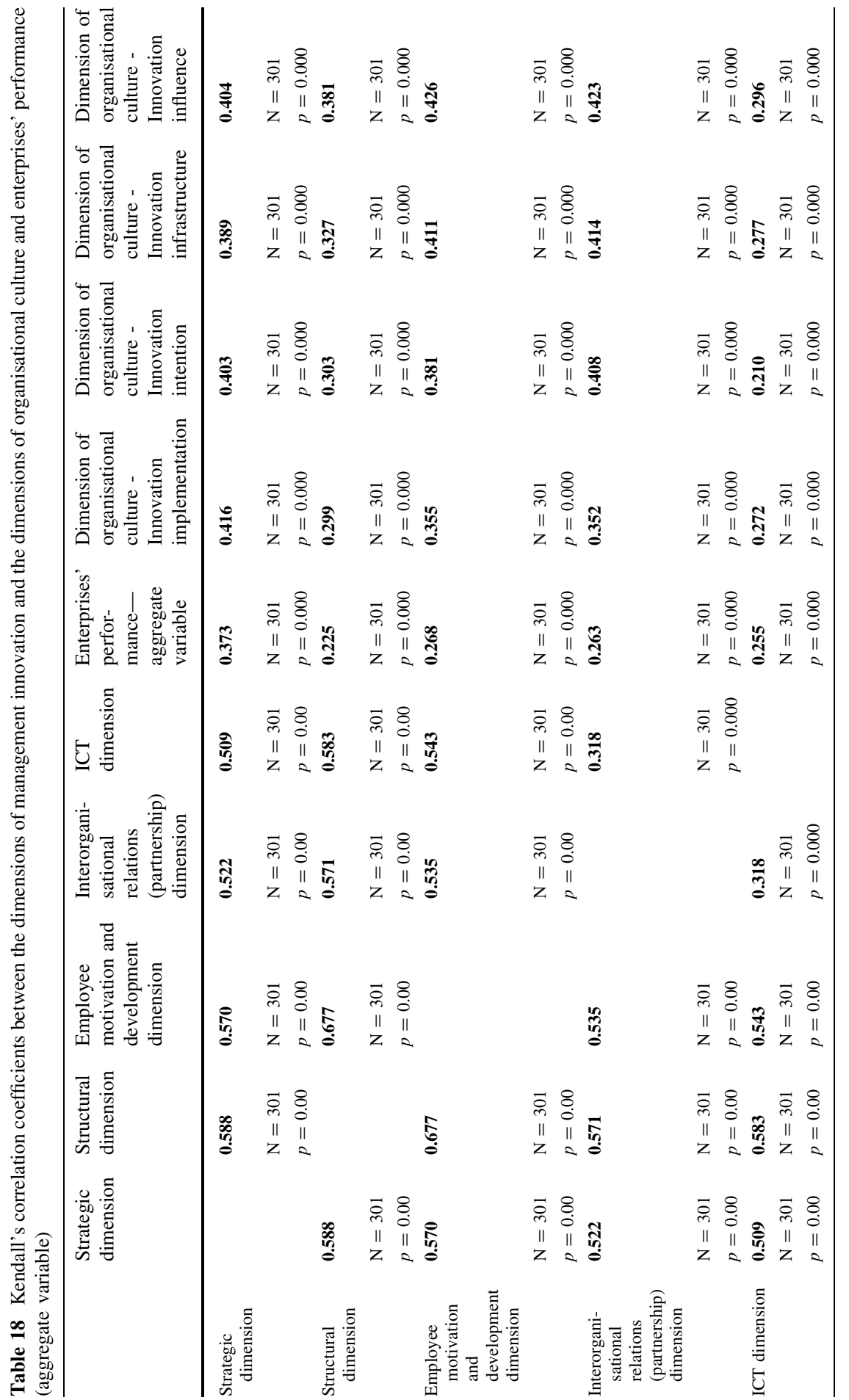




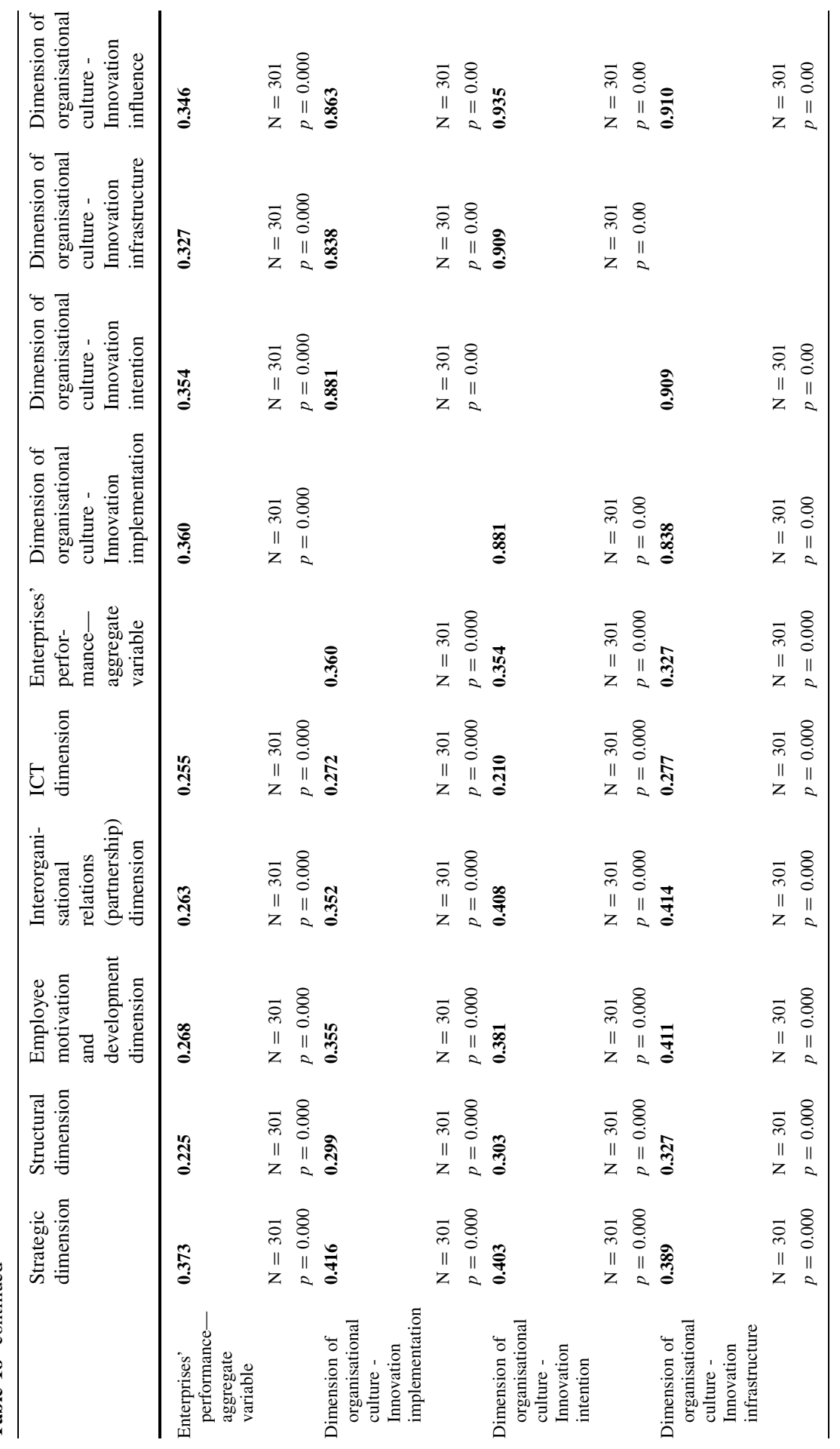




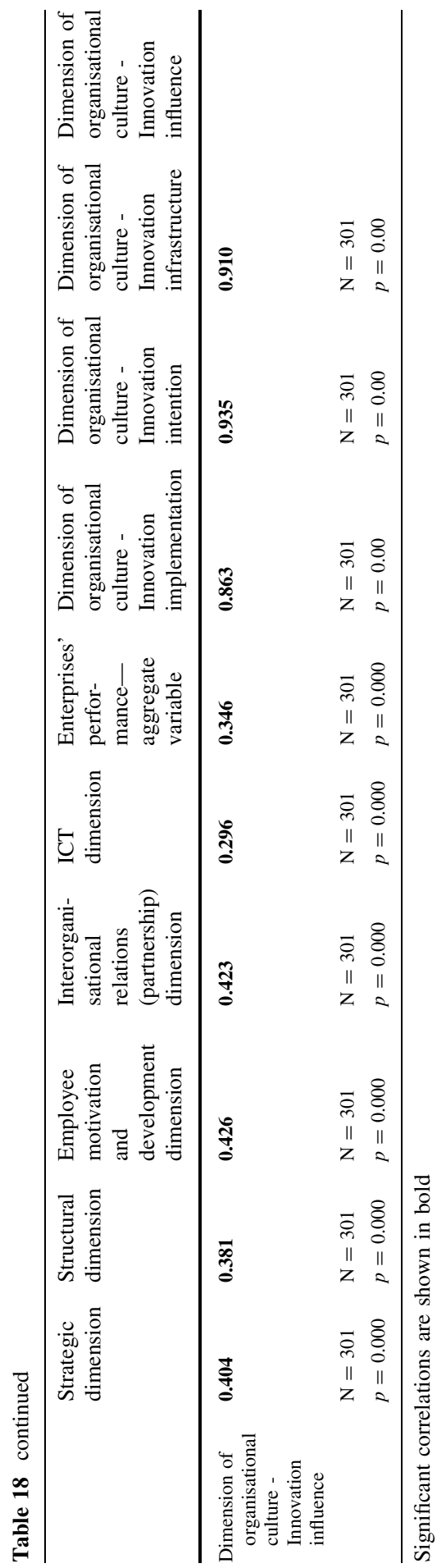




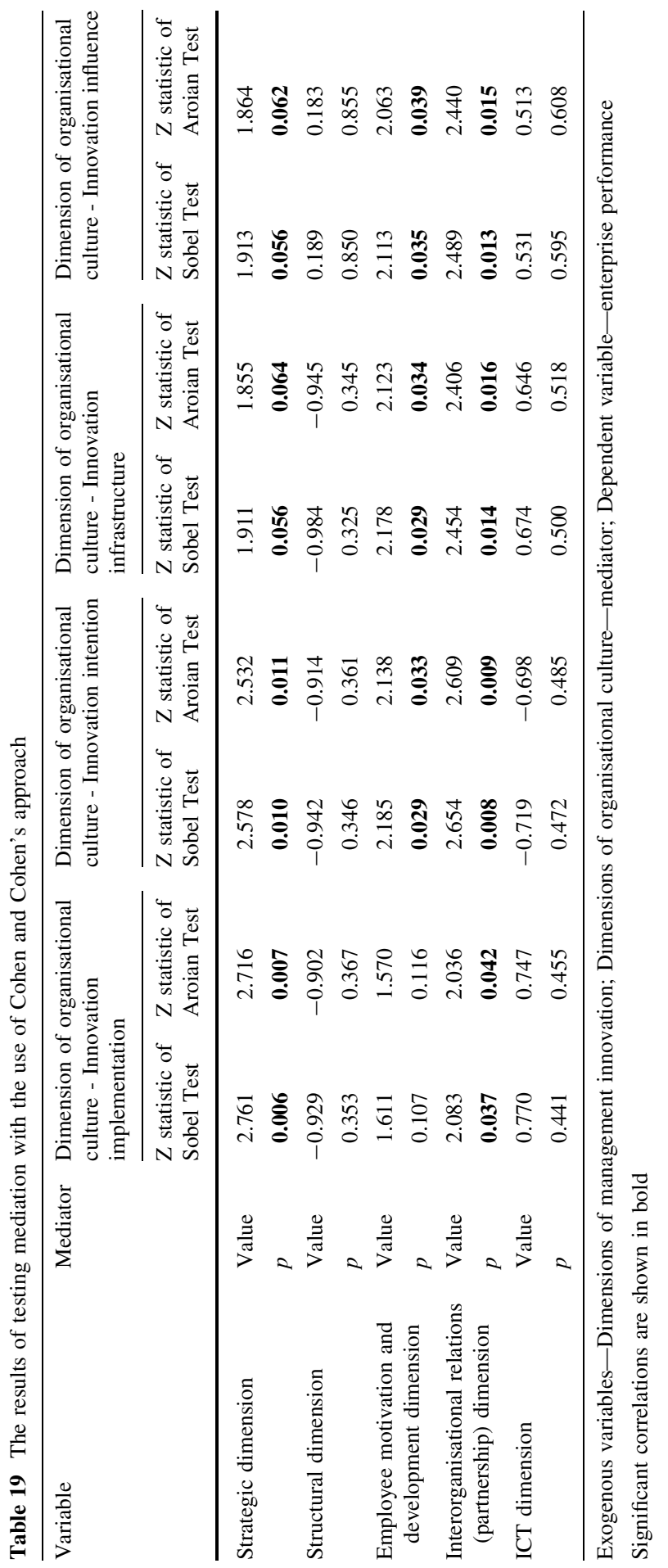




\section{References}

Abu-Jarad IY, Yusof N, Nikbin D (2010) A review paper on organizational culture and organizational performance. Int J Bus Soc Sci 1(3):26-46

Adams JD, Jaffe AB (1996) Bounding the effects of R\&D: an investigation using matched establishmentfirm data. RAND J Econ 27(4):700-721

Ahn-Sook H (2004) Integrating technology, marketing, and management innovation. Res Technol Manag 47(4):23-35

Alegre J, Lapiedra R, Chiva R (2006) A measurement scale for product innovation performance. Eur J Innov Manag 9(4):333-346

Antoncic B, Hisrich RD (2003) Privatization, corporate entrepreneurship and performance: testing a normative model. J Dev Entrep 8(3):197-218

Birkinshaw J, Mol MJ (2006) How management innovation happens. MIT Sloan Manag Rev 47(4):81-88

Birkinshaw J, Hamel G, Mol MJ (2008) Management innovation. Acad Manag Rev 33:825-845

Büschgens T, Bausch A, Balkin DB (2013) Organizational culture and innovation: a meta-analytic review. J Prod Innov Manag 30(4):763-781

Cameron KS, Quinn RE (1999) Diagnosing and changing organizational culture. Based on the competing values framework. Addison-Wesley, Reading, MA

Cameron KS, Quinn RE (2003) Kultura organizacyjna - diagnoza i zmiana. Oficyna Ekonomiczna, Kraków

Camisón C, Villar-López A (2014) Organizational innovation as an enabler of technological innovation capabilities and firm performance. J Bus Res 67:2891-2902

Cavagnoli D (2011) A conceptual framework for innovation: an application to human resource management policies in Australia. Innov Manag Policy Pract 13(1):111-125

Chang S-J, van Witteloostuijn A, Eden L (2010) From the editors: common method variance in international business research. J Int Bus Stud 41:178-184

Chien Y, Tsai-Fang Y, Chin-Cheh Y (2013) Knowledge sharing, organizational climate and innovative behavior: a cross-level analysis of effects. Soc Behav Personal 41(1):143-156

Coad A, Rao R (2008) Innovation and firm growth in high-tech sectors: a quantile regression approach. Res Policy 37(4):633-648

Cohen J, Cohen P, West SG, Aiken LS (2003) Applied multiple regression/correlation analysis for the behavioural sciences, 3rd edn. Erlbaum, Mahwah, NJ

Crossan MM, Apaydin M (2010) A multi-dimensional framework of organizational innovation: a systematic review of the literature. J Manag Stud 47(6):1154-1191

Damanpour F, Aravind D (2011) Managerial innovation: conceptions, processes and antecedents. Manag Org Rev 8(2):423-454

Danneels E (2008) Organizational antecedents of second-order competences. Strateg Manag J 29:519-543

Darroch J (2005) Knowledge management, innovation and firm performance. J Knowl Manag 9(3):101-115

De Tienne D, Mallette P (2012) Antecedents and outcomes of innovation-oriented cultures. Int J Bus Manag 7(18):1-11

Dobni CB (2008a) Measuring innovation culture in organizations. The development of a generalized innovation culture construct using exploratory factor analysis. Eur J Innov Manag 11(4):539-559

Dobni CB (2008b) The DNA of innovation. J Bus Strateg 29(2):43-50

Dobni CB (2010) The relationship between an innovation orientation and competitive strategy. Int J Innov Manag 14(2):331-357

Den Hertog P, Poot T, Meinen G (2006) Towards a better measurement of the soft side of innovation. In: Sundbo J, Gallina A, Serin G, Davis J (eds) Contemporary management of innovation. Palgrave Macmillan, NY

Eisenhardt K, Martin JA (2000) Dynamic capabilities: what are they? Strateg Manag J 21(10/ 11):1105-1121

Elenkov DS, Manev IM (2005) Top management leadership and influence on innovation: the role of sociocultural context. J Manag 31(3):381-402

Evangelista R, Vezzani A (2010) The economic impact of technological and organisational innovations: a firm-level analysis. Res Policy 39(10):1253-1263

Frohman A (1998a) Building a culture for innovation. Res Technol Manag 41(2):8-18 
Frohman AL (1998b) Building a culture for innovation. Res Technol Manag 41(2):9-12

Gallego J, Rubalcaba L, Hipp Ch (2012) Organizational innovation in small European firms: a multidimensional approach. Int Small Bus J 31(5):563-579

Hajro A (2015) Cultural influences and the mediating role of socio-cultural integration processes on the performance of cross-border mergers and acquisitions. Int J Human Res Manag 26(2):192-215

Hall B, Mairesse J (1995) Exploring the relationship between R\&D and productivity in French manufacturing firms. J Econom 65(1):263-293

Hecker A, Ganter A (2013) The influence of product market competition on technological and management innovation: firm-level evidence from a large-scale survey. Eur Manag Rev 10(1):17-33

Hee-Jae C, Pucik V (2005) Relationship between innovativeness, quality, growth, profitability, and market value. Strateg Manag J 26(6):555-575

Heij CV, Volberda HW, van den Bosch FAJ (2012) How does management innovation influence performance? EURAM 2012, Rotterdam

Heimonen T (2012) What are the factors that affect innovation in growing SMEs? Eur J Innov Manag 15(1):122-144

Hilami FM, Ramayah T, Mustapha Y, Pawanchik S (2010) Product and process innovativeness: evidence from Malaysian SMEs. Eur J Soc Sci 16(4):556-564

Hollen RMA, Van Den Bosch FAJ, Volberda HW (2013) The role of management innovation in enabling technological process innovation: an inter-organizational perspective. Eur Manag Rev 10:35-50

Jaskyte K (2004) Transformational leadership, organizational culture, and innovativeness in nonprofit organizations. Nonprofit Manag Leadersh 15(2):153-168

Jaskyte K, Kisieliene A (2006) Organizational innovation a comparison of nonprofit human-service organizations in Lithuania and the United States. Int Soc Work 49(2):165-176

Jassawalla AR, Sashittal HC (2002) Cultures that support product innovation processes. Acad Manag Exec 20(3):42-53

Khazanchi S, Lewis MW, Boyer KK (2007) Innovation-supportive culture: the impact of organizational values on process innovation. J Oper Manag 25(4):871-884

Kotter JP, Heskett JL (1990) Corporate culture and performance. The Free Press, New York

Kraśnicka T, Głód W, Wronka-Pośpiech M (2016) Management Innovation and its Measurement. J Ent Manag Innov 12(2):95-122

Kraus S, Pohjola M, Koponen A (2012) Innovation in family firms: an empirical analysis linking organizational and managerial innovation to corporate success. Rev Managerial Sc 6:265-286

Krot K, Lewicka D (2013) The market orientation as a key dimension of innovation culture-study of polish lingerie company. Int $\mathbf{J}$ e-Educ e-Bus e-Manag e-Learn 3(2):79-84

Lau CM, Ngo HY (2004) The HR system, organizational culture, and product innovation. Int Bus Rev 13(6):685-703

Malaviya P, Wadowa S (2005) Innovation management in organizational context: an empirical study. Glob J Flex Syst Manag 6(2):1-14

Manual O (2005) Guidelines for collecting and interpretnig innovation. OECD \& Eurostat, Paris

Marcoulides GA, Heck RH (1993) Organizational culture and performance: proposing and testing a model. Organ Sci 4(2):209-225

Martins E, Terblanche F (2003) Building organizational culture that stimulates creativity and innovation. Eur J Inn Manag 6(1):64-74

Meuer J (2013) Archetypes of inter-firm relations in the implementation of management innovation: a settheoretic study in China's biopharmaceutical industry. Organ Stud 35(1):121-145

Mol MJ, Birkinshaw J (2009) The sources of management innovation: when firms introduce new management practices. J Bus Res 62(12):1269-1280

Mol MJ, Birkinshaw J (2012) Relating management innovation to product and process innovation: private rents versus public gains. In: Pitsis TS, Simpson A, Dehlin E (eds) Handbook of organizational and managerial innovation. Cheltenham, Edward Elgar

Moreno-Luzon MD, Gil-Marques M, Valls-Pasola J (2013) TQM, innovation and the role of cultural change. Ind Manag Data Syst 113(8):1149-1168

Mothe C, Thi TUN (2010) The link between non-technological innovations and technological innovation. Eur J Innov Manag 13(3):313-332

Naranjo Valencia JC, Sanz Valle R, Jiménez Jimenez D (2010) Organizational culture as determinant of product innovation. Eur J Innov Manag 13(4):466-480

Nunnally JC (1978) Psychometric theory, 2nd edn. McGraw-Hill Book Company, New York, NY 
O'Relly CAI, Chatman J, Caldwell DF (1991) People and organizacional culture: a profile comparison approach to assessing person-organization fit. Acad Manag J 34(3):487-516

Ogbonna E, Harris LC (2010) Leadership style, organizational culture and performance: empirical evidence from UK companies. Int J Human Res Manag 11(4):766-788

Pichlak M (2012) Uwarunkowania innowacyjności organizacji. Studium teoretyczne i wyniki badań empirycznych, Difin, Warszawa

Prahalad CK, Krishnan MS (2008) The new age of innovation: driving co-created value through global networks. McGraw-Hill, NewYork

Rahimi G, Damirchi GV, Seyyedi MH (2011) Management behavior and organizational innovation. Interdiscip J Contemp Res Bus 3(3):78-95

Rosli MM, Sidek S (2013) The impact of Innovation on the performance of small and medium manufacturing enterprises: evidence from Malaysia. J Innov Manag Small Medium Enterp 2013:1-16

Salanova M, Agut S, Peiro JM (2005) Linking organizational resources and work engagement to employee performance and customer loyalty: the mediation of service climate. J Appl Psychol 90(6): 1217-1227

Schein EH (1996a) Culture: the missing concept in organizational studies. Adm Sci Q 41:229-240

Schein HE (1996b) Culture: the missing concept in organization studies. Adm Sci Q 41(2):229-240

Schumpeter JA (1960) Teoria rozwoju gospodarczego. PWN, Warszawa

Selltiz C, Wrightsman LS, Cook SW (1976) Research methods in social relations, 3rd edn. Holt, Rinehart and Winston, New York, NY

Shahzad F, Luqman RA (2012) Impact of organizational culture on organizational performance: an overview. Interdiscyp J Contemp Res Bus J 3(9):975-985

Sharifirad MS, Ataei V (2012) Organizational culture and innovation culture: exploring the relationships between constructs. Leadersh Organ Dev J 33(5):494-517

Sitko-Lutek A (ed) (2014) Kompetencje i kultura organizacyjna przedsiębiorstw w perspektywie międzynarodowej. Wydawnictwo Uniwersytetu M, Curie-Skłodowskiej, Lublin

Sørensen JB (2002) The strength of corporate culture and the reliability of firm performance. Adm Sci Q 47(1):70-91

Sułkowski Ł (2008) Czy warto zajmować się kulturą organizacyjną? Zarządzanie Zasobami Ludzkimi 6:9-25

Teece DJ (2007) Explicating dynamic capabilities: the nature and microfoundations of (sustainable) enterprise performance. Strateg Manag J 28:1319-1350

Terziovski M (2010) Innovation practice and its performance implications in small and medium enterprises (SMEs) in manufacturing sector: a resources-based view. Strateg Manag J 31:892-902

The Global Innovation Index (2015). https://www.globalinnovationindex.org/userfiles/file/reportpdf/GII2015-v5.pdf

Tidd J, Bessant J (2009) Managing innovation integrating technological, market and organizational change. Wiley, Hoboken

Timmerman JC (2009) A systematic approach for making innovation a core competency. J Qual Particip 31(4):4-11

Vaccaro IG, Jansen JJP, Van Den Bosch FAJ, Volberda HW (2012) Management innovation and leadership: the moderating role of organizational size. J Manag Stud 49(1):28-51

Volberda HW, Van Den Bosch FAJ, Heij CV (2013) Management Innovation: management as fertile ground for innovation. Eur Manag Rev 10(1):1-15

Walker RM, Damanpour F, Devece CA (2011) Management innovation and organizational performance: the mediating effect of performance management. J Publ Adm Res Theory 21(2):367-386

Wan CL, Ahmed PK (2004) The development and validation of the organizational innovativeness construct using confirmatory factor analysis. Eur J Innov Manag 7(4):303-313

Wang S, Guidice RM, Tansky JW, Wang ZM (2010) When R\&D spending is not enough: the critical role of culture when you really want to innovate. Human Res Manag 49(4):767-792

Wei Y, O'Neill H, Lee RP, Zhou N (2013) The impact of innovative culture on individual employees: the moderating role of market information sharing. J Prod Innov Manag 30(5):1027-1041

Wood RC (2007) How strategic innovation really gets started. Strateg Leadersh 35(1):21-29

Yeh-Yun LC, Feng-Chuan L (2012) A cross-level analysis of organizational creativity climate and perceived innovation: the mediating effect of work motivation. Eur J Innov Manag 15(1):55-76

Zdunczyk K, Blenkinsopp J (2007) Do organisational factors support creativity and innovation in Polish firms? Eur J Innov Manag 10(1):25-40 